\title{
WILL INFORMAL INSTITUTIONS REPLACE FORMAL INSTITUTIONS? THE PRIMACY OF CHURCH AND "UMA LISAN" IN FOSTERING COMMUNITY SECURITY IN TIMOR LESTE
}

\author{
Sugito, Tulus Warsito, Achmad Nurmandi, Zuly Qodir ${ }^{1}$ \\ Universitas Muhammadiyah, Yogyakarta
}

\begin{abstract}
:
This article departs from liberal institutionalism theory which argues that security sector reform is an important element to guarantee community security in post-conflict state. Nevertheless, this article discovers that Security Sector Reform run by the United Nations in Timor Lester from 2000-2012 failed to provide effective community security. While the people of Timor Leste have their own perceptions about the meaning of security, religious and cultural institutions, the church and "uma lisan" have provided mainly social protection and mechanisms for conflict resolution. Based on in-depth interviews with 15 key informants and survey to 100 respondents during the field research in Dili, this article suggests that the security role of the church and "uma lisan" has substantially substituted the ineffectiveness of the international and state-led security institutions during the United Nations mission in the country.
\end{abstract}

Keywords: Security Sector Reform, United Nations, Timor Leste, “uma lisan”, Church, Institutional Substitution.

Título en Castellano: Las Instituciones Informales sustituyen a las Instituciones Formales: El Papel de la Iglesia y de 'Uma Lisan' para reforzar la seguridad de la población de Timor-Leste

\section{Resumen:}

Este artículo aborda la teoría del institucionalismo liberal que sostiene que la reforma del sector de la seguridad es un elemento clave para garantizar la seguridad dentro de las comunidades en situaciones de posconflicto. Sin embargo, a través de una investigación empírica, este artículo demuestra que el fracaso de la reforma del sector de la seguridad en Timor-Leste no tuvo un impacto significativo en la seguridad comunitaria. Aunque la población de Timor Leste cuenta con sus propias percepciones de seguridad, las instituciones religiosas y culturales, en particular la Iglesia católica y 'uma lisan' han aportado mecanismos de resolución de conflictos y protección social. Tras las entrevistas en profundidad realizadas con 15 informantes clave y a 100 encuestados durante la investigación de campo en Dili, este artículo sugiere que el papel securitario de la Iglesia y "uma lisan" ha suplido sustancialmente la ineficacia de las instituciones de seguridad internacionales y las dirigidas por el Estado durante la misión de las Naciones Unidas en el país.

Palabras Clave: Reforma del Sector Seguridad, Naciones Unidas, Timor-Leste, 'uma lisan', Iglesia, sustitución institucional

Copyright $\odot$ UNISCI, 2019.

Las opiniones expresadas en estos artículos son propias de sus autores, y no reflejan necesariamente la opinión de UNISCI. The views expressed in these articles are those of the authors, and do not necessarily reflect the views of UNISCI.

\footnotetext{
${ }^{1}$ Sugito is a Ph.D. candidate of Doctoral Program of Islamic Political Studies-Political Science, Universitas Muhammadiyah Yogyakarta and Lecturer at the Department of International Relations of Universitas Muhammadiyah Yogyakarta. E-mail:<sugito@umy.ac.id>. Tulus Warsito is Professor at the Department of International Relations, Universitas Muhammadiyah Yogyakarta. E-mail: <tulusw_umy@yahoo.com>. Achmad Nurmandi is Professor at the Department of Government Affairs and Administration, Jusuf Kallla School of Government, Universitas Muhammadiyah Yogyakarta. E-mail: <nurmandi_achmad@umy.ac.id>.Zuly Qodir is Lecturer at Islamic Politics-Political Science Universitas Muhammadiyah Yogyakarta. E-mail:
} <zuly_qodir@yahoo.com>

DOI: http://dx.doi.org/10.31439/UNISCI-84 


\section{Introduction}

The United Nations' (UN) Security Sector Reform (SSR) mission in Timor Leste for more than a decade (2000-2012) has successfully established formal security institutions, i.e. the Polícia Nacional de Timor-Leste-PNTL (National Police of Timor Leste), the Falintil-Forças Armadas de Defesa de Timor-Leste-F-FDTL (Timor Leste Defense Forces), and judicial institutions. However, the existence of PNTL and F-FDTL has yet to provide security and peace. They even became a proximate factor of violent conflict in 2006 which turn into ethnic conflict in society ${ }^{2}$. Political and ethnic conflicts in 2006-2008 were evidence of the collapse of Timor Leste's security institutions. UNTAET and the government of Timor Leste did not appear to be sufficient to build a national consensus on security needs and the types of power needed. The government at that time did not have a national security policy and there were still loopholes in the legislation relating to security. The absence of a political consensus has resulted in the inability of police and military to escape from political interference ${ }^{3}$.

After the conflict, UN Integrated Mission in Timor Leste (UNMIT) together with the Timor Leste government rebuilt the security institutions with a series of reforms on structural, instrumental, and cultural aspects ${ }^{4}$. Structural reform was all forms of organizational changes, institutions, councils, institutions as well as organizational duties and responsibilities. Reform of the instrumental aspect was performed by changing several laws related to security and the police, internal regulations or organizational procedures. The government succeed in passing The National Security Act or Lei Seguransa National Law no 2 of 2010 and the Domestic Security Act no 4 of 2010 as a foundation to build security institutions. In cultural aspects, UNMIT reformed organizational culture and organizational habits. UNMIT has completed 451 of the 559 trainings and capacity building activities (or 81 percent) of the planned activities. Some notable achievements are including the establishment of a forensic laboratory, the development of PNTL work descriptions and staffing tables, and the creation of an armory and archiving database. In addition, PNTL officers have attended 11,634 training sessions in Jakarta on issues of legislation, discipline, administration, human rights, gender awareness, domestic violence law, petty cash management, arrest procedures, public order management, leadership, supervision, closed protection, information technology, map reading, command and control, armory management, forensics and intelligence gathering. Until 2012, the number of PNTL personnel reached 3,386, of whom 598 were female police officers ${ }^{5}$. Justice reform in TimorLeste has largely focused on building institutional and human capacity. The Government of Timor Leste together with UNMIT agreed to continue with the consolidation of peace and stability, focusing on further drafting and enacting laws, increasing access to justice for all, and regulating the relationship of the traditional/customary justice system with law and legal mechanisms.

Although the UN has implemented a series of programs to strengthen the security sector in Timor Leste, the outcomes have been ineffective with numerous institutions failed to work professionally and independently. PNTL as an institution faces significant internal and operational challenges, which continue to hamper the effectiveness of the entire organization and its ability to provide proactive security services consistently. These challenges include

\footnotetext{
${ }^{2}$ Valters, Craigs., Dewhurst, Sarah., \& de Catheu, Juana. (2015): After the Buffaloes Clash Moving From Political Violence to Personal Security in Timor Leste (Case Study Report Security). London: Overseas Development Institute.

${ }^{3}$ Radin, Andrew (2012): “A Laboratory for State Building: Police and Military Reform in East Timor”, Working Paper, No. 2012-11, Massachusetts, Massachusetts Institute of Technology Political Science Department.

${ }^{4}$ Ramos, Arquimino Bianco Leuidi (2014): Reformasi Sektor Keamanan, Kupang, Gita Kasih, pp 21-24.

${ }^{5}$ UN Security Council. (2012): Report of the Secretary-General on the United Nations Integrated Mission in Timor-Leste (for the period from 7 January through 20 September 2012), Number: S/2012/765, New York, UN Security Council.
} 
inadequate investigative skills, low human and physical resources, unclear leadership structures, and not to mention the lack of job descriptions ${ }^{6}$. In the judicial system, for instance, many judges and lawyers are inexperienced and untrained for their current positions. And while the support services for the court are still limited, investigators are hampered by the difficulties in getting translations into and from English, Portuguese, and many local languages. As a result, courts are unable to resolve many cases, sparking protests from prisoners in Becora, Gleno, Baucau, and Oecusi who had not yet gone through the judicial process after being detained for so long $^{7}$.

Ineffectiveness of formal institutions has brought about people's distrust. In a security perception survey conducted by the Asia Foundation in 2008, it was found that nationally only few people $(15 \%)$ or community leaders $(21 \%)$ believed that the PNTL had the primary responsibility for maintaining security in their area. Overall, three-quarters of the population felt that local leaders (chef suco/head of village), traditional elders, and community leaders, in general, were responsible for maintaining security in their area. Even in Dili, which was the center of the conflict in 2006-2008, only $15 \%$ of the general public said PNTL had the primary responsibility for maintaining security ${ }^{8}$. Furthermore, based on a survey of law and justice conducted by the Asia Foundation in 2013, it was stated that the majority of people in Timor Leste were more confident and comfortable with the local court system. The same survey also confirmed that although $88 \%$ of the respondents had knowledge of the court, the majority $(93 \%)$ still felt more comfortable with local or adat justice administrators ${ }^{9}$.

Some researchers concluded that UN has failed to build security institutions in Timor Leste. This failure appears in the emergence of an authoritarian government in Timor Leste ${ }^{10}$, conflicts between F-FDTL and PNTL which resulted in insecurity in 2006-2008 ${ }^{11}$ and public distrust in PNTL and the judiciary ${ }^{12}$. The malfunction of the country's security institutions has implications for Timor Leste's dependence on the presence of the UN and makes it a "new style trusteeship state" (neo-trusteeship) ${ }^{13}$. The PNTL and F-FDTL development in East Timor under the UN is largely a story of slipshod planning, squandered opportunities, and unimaginative leadership ${ }^{14}$.

Although formal institutions failed to foster security for the people of Timor Leste, it was found that the community still felt secure and even improved from 2006-2015. This condition is

\footnotetext{
${ }^{6}$ Wassel, Todd and Rajalingam, Gobie (2013): A Survey of Community-Police Perceptions in Timor-Leste, 2013 Survey, San Francisco, The Asia Foundation.

${ }^{7}$ UN Security Council (2002): Report of the Secretary-General on the United Nations Transitional Administration in East Timor, Number S/2002/432, New York, UN Security Council

${ }^{8}$ Chinn, Liam and Everett, Silas (2008): A Survey of Community-Police Perceptions Timor-Leste in 2008, San Francisco, The Asia Foundation

${ }^{9}$ Marx, Susan (2103): Timor Leste Law and Justice Survey 2013, San Francisco, the Asia Foundation.

${ }^{10}$ Chopra, Jarat: "Building State Failure in East Timor", Development and Change, Vol. 33, no 5 (November 2002), pp. 979-1000.

${ }^{11}$ Its impacts were founded in many research by some scholars, such as Wilson, Bu V. E.: To 2012 and Beyond: International Assistance to Police and Security Sector Development in Timor-Leste. Asian Politics and Policy, Vol 4, no 1, (2012), pp. 73-88. https://doi.org/10.1111/j.1943-0787.2011.01320.x; Uesugi, Yuji.: "Security Sektor Reform (SSR) in Timor-Leste: the Challenges of Respecting Local Ownership", Asia Peacebuilding Inisiatives, (2014); Gordon, Eleanor: "Security Sector Reform, Local Ownership and Community Engagement. Stability", International Journal of Security \& Development, Vol. 3, nº 1 (2014), pp. 1-18, at http://dx.doi.org/10.5334/sta.dx.;

12 Grenfell, Damian., \& Winch, Bronwyn.(2014): Local Security And Resilience in Dili, Centre For Global Research and the Asia Foundation.

${ }^{13}$ Butler, Michael J. : “Ten Years After: (Re) Assessing Neo-Trusteeship and UN State-building in Timor-Leste”, Journal of International Stuides Perpectives, Volume 13, nº 1 (February 2012), pp. 85-104.

${ }^{14}$ Hood, Ludovic.: "Security Sector Reform in East Timor, 1999-2004", International Peacekeeping, Vol. 13, ${ }^{\circ}$ 1 (2006), pp.60-77, at https://doi.org/10.1080/13533310500424819
} 
strengthened by a survey conducted by the Asia Foundation in 2008 showing that $53 \%$ of the community felt that the safety of their environment was safer, $41 \%$ felt the same as in previous years, and only $3 \%$ felt security worsened ${ }^{15}$. The same survey was conducted in 2013 where the results showed that $73 \%$ of the population felt safer, $22 \%$ stated the same, and $1 \%$ was the same while the rest stated they did not know ${ }^{16}$. This phenomenon was interesting to study why did East Timorese people feel secure even though Timor Leste's security institutions were weak in performing their functions?

\section{Theoretical Background}

Security is considered a contested concept ${ }^{17}$ and is based on four levels of explanation, i.e. philosophy, reference objects, issues, and efforts to achieve ${ }^{18}$. Philosophically, security can be seen as an accumulation of power or emancipation. Security as an accumulation of power is in line with the idea that security is a condition free from fear and threats of violence ${ }^{19}$. This epistemology views that power (especially military power) becomes an essential factor for achieving security and the more powerful the actor has, the greater the security that will be gained. Meanwhile, security as emancipation or enabling considers that security is not a commodity, but security is the relationship between actors. Security is a relationship between actors who trust each other and share commitments to eliminate threats and provide peaceful conditions and predictability. As a consequence of this philosophy, security will not be achieved by optimizing unilateral forces, but on cooperation between actors or multilateral approach to achieve "common security".

The debate about security can also be explored from various security reference objects. Basically, speaking of security means referring to humans. Humans become an important object considering there is no state security without a sense of security possessed by humans. ${ }^{20}$ National Security dominated the security studies during the Cold War. The development of security studies also concerns the increasingly widespread issues being discussed. The dominance of the realist views in the 1950s to 1960s placed the issues of armed conflict and the use of the military in warfare as the main discussion on security. This military issue was later reconsidered by the researchers, expanding the concept of security to cover non-military issues such as politics, economics, social, and environment. Later, the concept of human security emerged and was not only related to military security, addressing widespread and cross-cutting challenges to the survival, livelihood and dignity of the people.

Axiologically, security studies have helped governments, non-governmental actors, and international organizations make policies or programs for providing security to states and human beings. Starting from the philosophy of security as accumulation of power, government built their military capability and alliance with the other state for survival. Security, that is based on an epistemology of enabling, directs multi actors to create secure spaces, building capacities and capabilities, and enabling to produce security and maintain justice ${ }^{21}$. Related to this perspective, the United Nations (UN) believe that democratic states will provide more secure spaces in international relations. Therefore, the UN will always try to transform former conflict countries into liberal democracies through state building. State-building is a set of policies and actions undertaken by national and/or international actors to develop, reform and strengthen

\footnotetext{
${ }^{15}$ See Chinn, Liam and Everett, Silas, op.cit.

${ }^{16}$ Wassel, Todd and Rajalingam, Gobie. op.cit.

${ }^{17}$ Baldwin, David A.: "The Concept of Security", Review of International Studies, Vol. 23, n 5 (1997), p.26.

${ }^{18}$ William, Paul D. (2008): Security Studies: an Introduction, London, Routledge, pp. 5-10.

${ }^{19}$ Gjørv, Gunhild Hoogensen.: "Security by Any Other Name: Negative Security, Positive Security, And a MultiActor Security Approach", Review of International Studies, Vol 38, nº 4 (2012), pp. 835-859, at https://doi.org/10.1017/S0260210511000751

${ }^{20}$ Willian, Paul. D, op.cit.

${ }^{21}$ Gjørv, Gunhild Hoogensen, op. cit.
} 
state/formal institutions where these have been seriously eroded or are missing ${ }^{22}$. However, similar with peacebuilding, the concept of state building has also significantly evolved over time. There has been a significant change within the international donors towards recognizing that the state cannot be developed in isolation and that state-society relations are central to statebuilding processes. Therefore, state building has become more "responsive" and has to be understood in terms of an effective political process through which citizens and the state can negotiate mutual demands, obligations, and expectations. These changes took place putting the concept of legitimacy - both as a means to building state capacity and as an end in itself-at the center of the state-building agenda ${ }^{23}$.

Security sector refers to a model of security assistance now at the heart of state-building policies and practices, widely perceived as a prerequisite for stability and sustainable development in countries recovering from conflict or making transitions from authoritarianism, fragility or collapse ${ }^{24}$. State security is believed to be a precondition for sustainable development ${ }^{25}$. The security sector includes all organizations that have the authority to use (or order to use) force or threat to protect the state and society, as well as civil structures that are responsible for the management of public security ${ }^{26}$. Therefore, the SSR is a reform process aimed at the military, intelligence, police, penal system, and justice. This reform aims to improve the ability of the security sector and also to improve accountability, oversight and security governance by civil authorities ${ }^{27}$. The DAC articulates the objective of SSR as follows: to increase partner countries' ability to meet the range of security needs within their societies in a manner consistent with democratic norms and sound principles of governance, transparency and the rule of law. SSR includes, but extends well beyond, the narrower focus of more traditional security assistance on defense, intelligence and policing ${ }^{28}$

The way the UN and other donor agencies conduct SSR especially in Timor Leste received huge attention from researchers. The most significant criticism presented to the UN is the ability of leadership ${ }^{29}$, local ownership involvement ${ }^{30}$, program sustainability $^{31}$, and the accuracy of SSR program priorities ${ }^{32}$. In addition, SSR obstacles also arise from the lack of openness and inclusiveness of donor countries to invite all parties concerned with security ${ }^{33}$

\footnotetext{
${ }^{22}$ Menocal, Alina Rocha: "State Building for Peace: ¿a New Paradigm for International Engagement in PostConflict Fragile States?”, Third World Quarterly, Vol. 32, No. 10, (2011, pp. 1715-1736

${ }^{23}$ Ibid.

${ }^{24}$ Sedra, Mark: "The Evolution of the Security Sector Reform Agenda", in Sendra, Mark. (ed.), (2010): The Future of Security Sector Reform, Canada: The Centre for International Governance Innovation.

${ }^{25}$ Besenyő, János (2019): "Barry Buzan's Securitization Theory and the Case of Iraqi Kurdish Military Action Against ISIS in 2014", Journal of Security and Sustainability Issues 8(3): 295-306. http://doi.org/10.9770/jssi.2019.8.3(1)

${ }^{26}$ Jackson, Paul: " Security Sector Reform and State Building", Third World Quarterly, Vol. 32, No. 10, (2011), p.1804.

${ }^{27}$ Onoma, Ato Kwamena: "Transition Regimes and Security Sector Reforms in Sierra Leone and Liberia", WIDER Working Paper, No. 012, (Januari 2014), at http://hdl.handle.net/10419/96283.

${ }^{28}$ OECD DAC. (2007): OECD DAC Handbook on Security System Reform. Paris: OECD, in United Nation: "Securing Peace and Development: The Role of the United Nations in Supporting SSR." Report of the SecretaryGeneral. A/62/659-S/2008/39. (January 23, 2008).

${ }^{29}$ See Jackson, Paul, op.cit; also Wassel, Todd. (2014): Timor-Leste : Links Between Peacebuilding, Conflict Prevention and Durable Solutions to Displacement, Washington, D.C.: Brookings Institution.

${ }^{30}$ See Chopra, op.cit; Jackson, op.cit; Schroeder, Ursula C., Chappuis, Fairlie., \& Kocak, Deniz: "Security Sector Reform and the Emergence of Hybrid Security Governance", International Peacekeeping, Vol. 21, No.2, (2014), pp. 214-230. https://doi.org/10.1080/13533312.2014.910405; Simangan, Dahlia: "A Detour in the Local Turn: Roadblocks in Timor-Leste's Post-Conflict Peacebuilding", Asian Journal of Peacebuilding, Vol 5, n 2 (January 2017), pp. 195-221.

${ }^{31}$ See Jackson, op.cit.

32 Ibid

${ }^{33}$ See Onoma, op.cit.
} 
and a very striking difference between donor understanding and expectations with local people $^{34}$. Although the UN has been criticized for its failure to establish a professional and effective East Timorese security institution, it does not mean that the community is in a state of insecurity. In fact, the people of Timor Leste feel that their security conditions are stable and even tend to improve ${ }^{35}$. Such feeling of security from the society despite the inefficiency of formal institutions promoted by the UN is the main concern of this research through applying the perspective of relations between informal and formal institutions in the security sector.

The presence of informal institutions is an important determinant of the success of development. Non-state institutions or informal institutions are usually unwritten social rules that are formed, communicated, and enforced with non-formal sanctions ${ }^{36}$. These informal institutions provide guidelines for individuals to behave and sometimes provide penalties for those who violate them by self-enforcing ${ }^{37}$. Therefore, what is meant by informal security institutions are routines, rules, or social norms that are able to present a sense of security and support the peaceful resolution of conflicts in society without using state-legal instruments. Formal institutions reflect a social reality, which then forms cohesiveness and coordination among individuals in the community. Furthermore, the two institutions will mutually reinforce the beliefs, values, norms, and priorities in society. However, sometimes it is the informal institutions and local power rather than the state's central power that are typically more trusted by society ${ }^{38}$.

The pattern of relations between informal and formal institutions can be categorized in four forms ${ }^{39}$. First, complementary (complete each other) when formal institutions are effective and share the same goals with informal institutions that become partners. Therefore, formal and informal can coexist peacefully and cooperate with each other or in parallel. Second, accommodating, when an effective formal institution has different results from informal institutions, thus limiting its influence and peaceful opposition. This pattern is identical to the coordination function performed by informal institutions when there is an overlap between informal and formal functions. Third, substitutive (replacing) where weak formal institutions require informal institutions to achieve common interests. This substitutive type is identical to the completing pattern in which informal institutions will complement existing formal institutions by filling in the gaps in the existing formal institutions. Fourth, competing, when formal institutions are weak and have different outputs from informal institutions that cause it to compete to dominate institutions.

\footnotetext{
${ }^{34}$ See Armstrong, Nicholas. J., Chura-beaver, Jacqueline., \& Kfir, Isaac (2012): Security Sector Reform in TimorLeste : Missed Opportunities and Hard Lessons in Empowering the Host-Nation, Pennsylvania: Peacekeeping and Stability Operations Institute (PKSOI); Blanco, Ramon: "The UN Peacebuilding Process: an Analysis of Its shortcomings in Timor-Leste", Revista Brasileira de Política Internacional, Vol. 58, $\mathrm{n}^{\circ}$ 1, pp. 42-62, https://doi.org/10.1590/0034-7329201500103; also Kohl, Christoph ; Hessische Stiftung Friedens- und Konfliktforschung (ed.): "The Reform of Guinea-Bissau's Security Sector: Between Demand and Practice", PRIF Reports No 126, (2014); Kohl, Christoph: "The reform of Guinea-Bissau's security sector: between demand and practice", PRIF, 2014, at http://nbn-resolving.de/urn:nbn:de:0168-ssoar-435339.

${ }^{35}$ Chinn, Liam and Everett, Silas, op.cit.

${ }^{36}$ See Helmke, Gretchen. and Levitsky, Steven: "Informal Institutions and Comparative Politics: a Research Agenda", Perspective on Politics, Vol 1, nº 4, (December 2004), pp. 725-740.; Azari, Julia. R., \& Smith, Jennifer. K: "Unwritten rules: Informal Institutions in Established Democracies", Perspectives on Politics, Vol. 10, $\mathrm{n}^{\circ} 1$ (2012), pp.37-55.at https://doi.org/10.1017/S1537592711004890

${ }^{37}$ See Azari and Smith, op. cit

${ }^{38}$ Menocal, op.cit.

${ }^{39}$ Helmke and Levitsky, op.cit, pp 726-730.
} 


\section{Table 1. Typology of an Informal Institution}

\begin{tabular}{|c|c|c|}
\hline & Effective Formal Institutions & Ineffective Formal Institutions \\
\hline Compatible Goals & Complementary & Substitutive \\
\hline Conflicting Goals & Accommodating & Competing \\
\hline
\end{tabular}

Source: Helmke, Gretchen. and Levitsky, Steven: "Informal Institutions and Comparative Politics: A Research Agenda", Perspective on Politics, Vol 1, nº. 4, (December 2004), p. 728.

Referring to the typology of the relationship between formal and informal institutions, this research argues that the relation of substitution between state security institutions and traditional institutions has occurred in Timor Leste. The church and "uma lisan" (traditional secret house), substituted the role of PNTL, F-FDTL, and state court institutions in providing security and conflict resolution for the people of Timor Leste. The role of church security as well as "uma lisan" can be traced from Johan Galtung's (1996) conception of conflict and conflict transformation. Galtung explained that conflict can be a security threat in the form of structural, cultural, or direct violence. Efforts that can be made to eliminate such violence are peacebuilding, peacemaking, and peacekeeping. Peacemaking is in the form of persuasion education efforts to eliminate negative attitudes in conflict and also cultural violence. Peacekeeping seeks to stop violence and direct violence. Meanwhile, peacebuilding seeks to provide a stronger foundation to prevent the re-emergence of violent conflict by eliminating existing sources of contradiction and structural violence ${ }^{40}$. Based on this, the church and "uma lisan" play a role in eliminating negative attitudes in conflict that result in violence and insecurity (peacemaking) as well as providing mechanisms for peaceful resolution of conflicts and physical protection to the community from violence or insecurity (peacekeeping).

\section{Objective and Methodology}

This study aims to identify the role of the church and "uma lisan" in providing security to the Timorese society, especially during 1999-2012 when the UN held its peace mission in Timor Leste. Applying institutional relations perspective, this research underlines the substitutive relations between informal and formal institutions in providing security and conflict resolution mechanisms in Timor Leste. The applied research method was mixed method (qualitative and quantitative) with convergent parallel mixed methods design. In this approach, both quantitative and qualitative data are collected, being analyzed separately, and then compared to find the result that can confirm or disconfirm each other ${ }^{41}$. The research location was in Dili District, the capital of Timor Leste. The location selection was based on the consideration that the city was the center of the riots in 1999 and 2006-2008. In addition, Dili as the national capital, has a relatively high ethnic heterogeneity. In Dili, almost all people from 12 other districts stayed to study and work. The selection of the city of Dili was also based on the ease of researchers in obtaining interview data. Most Dili people can speak Indonesian and English besides Tetun and Portuguese. Dili also has a diocese, the Cathedral Church, and several other churches that had a role in the history of struggle and conflict in Timor Leste. Meanwhile, "uma lisan" was in Ermera district, which is $44 \mathrm{KM}$ from the city of Dili.

During the field research di Dili, 15 informants were interviewed and 100 questionnaires were distributed. Qualitative data obtained from interviews are made into statements in the questionnaire which were distributed to 100 respondents representing 13 districts in Timor Leste and also Lorosa'e-Loromanu people. The determination of participants was done by the

\footnotetext{
${ }^{40}$ Miall, Hugh. (2004): Conflict Transformation: A Multi-Dimensional Task, Berlin: Berghof Research Center for Constructive Conflict Managementat, at http://www.berghof-handbook.net

${ }^{41}$ Creswell, John.W. (2014): Research Design: Qualitative, Quantitative, and Mixed Methods Approaches, Thousand Oaks, Sage Publication.
} 
snowballing method. The categories of participants in this study were people who experienced conflicts in 1999 and 2006-2008, church members, church leaders, and "uma lisan" leaders. The researchers first held an open discussion with students, NGOs, and academics at the East Timor National University (UNTL) to explain the research proposal. From this discussion, researchers found preliminary information and also some credible participants to be interviewed. Qualitative data analysis was done by interpreting the meaning of the views and experiences conveyed by participants. To reduce the possibility of misinterpretation, researchers used a combination of triangulation procedures and data source procedures. Triangulation of methods was by comparing information from one informant with other informants, as well as from interviews with observations. Meanwhile, researchers triangulated data sources by cross-checking interviews with other data sources, i.e. statements of respondents' attitudes in the form of questionnaires, archives, personal writings, photos, or other documents.

Triangulation of data sources was done through the distribution of questionnaires to 100 respondents with purposive random sampling technique. Samples were people who had experienced conflicts in 1999 and 2006-2008. Based on Gender, the respondents of this study were $57 \%$ male and $43 \%$ female. Meanwhile, based on age, respondents in this study ranged from 20 years to 59 years, so they experienced periods of conflict after the referendum in 1999 and conflicts in 2006-2008. The respondent's breakdown is based on age, as in Figure 1. Below

Figure 1. Respondents by Age

\begin{tabular}{|l|l|l|}
\hline Age (years) & $\mathbf{N}^{\mathbf{o}}$ & Percent \\
\hline $20-29$ & 52 & 52.0 \\
\hline $30-39$ & 23 & 23.0 \\
\hline $40-49$ & 16 & 16.0 \\
\hline $50-59$ & 9 & 9.0 \\
\hline Total & 100 & 100.0 \\
\hline
\end{tabular}

The plurality of the population in the city of Dili has been represented in the profile of respondents in this study. Of the 13 districts in Timor Leste, 12 of them were respondents in this study. One Lautem district, however, had no representation. Meanwhile, if it was divided into two major regions, they were western part of Timor (Loromanu) and East part of Timor (Lorosa'e), both of them were represented by $19 \%$ in the east and $81 \%$ in the west.

\section{Figure 2. Respondents by Origin}

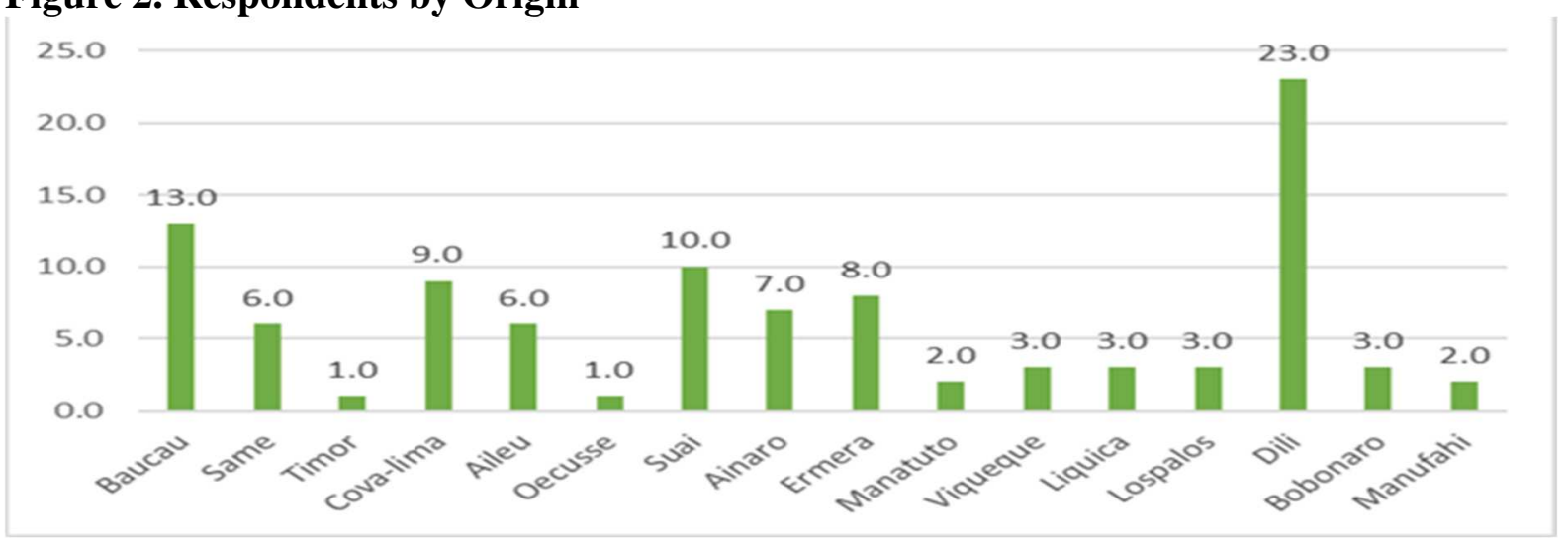




\section{The Role of "Uma Lisan" in Providing Security and Settlement of Conflicts in the Community}

The "uma lisan" has become the center of Timorese people activities long before the introduction of the Church and modern government. "Uma lisan" is led by "lia nain" (traditional leader) who is the oldest person and plays the role as a guard and, at the same time, has the power to use "lulik" (secret things). "Lia nain" carries out various duties in society, such as leading traditional ceremonies, giving "hamulak" (mantras) to "boa malus" (betel nut) both for health and safety, and resolving disputes among citizens (FBP, 11/26/2018). "Uma lisan" usually copes with several houses that are still in a lineage. However, in one line of descent, some families can form another "uma lisan" with the main "uma lisan" which was first built. In "suco" (Village) Riheu, district Ermera, there are four "uma lisan", i.e. Metrisi, Buigore, Aigor, and Lakateu. Metrisi was the first house built and three other traditional houses were built by the younger siblings of the founder of Metrisi (FBP, 11/26/2018).

"Uma lisan" as a source of security and harmony can be found in three performed main activities. First, at each time of the corn harvest, people will bring their harvests to "uma lisan" to ask for prayer from lia nain. Second, when there is a wedding ceremony since the application until the implementation. Third, at the end of each year "lia nain" will call all its members to return to "uma lisan" to visit "lia nain" and discuss matters relating to "uma lisan".

Di dalam rumah adat ("uma lisan"), siapa yang tertua dia jadi pemimpin, dia tidak kemana mana di tempat itu selama hidup. Tujuannya selama dia menunggu rumah itu adalah memimpin acara adat. Pertahunan ada 2-3 kali acara adat. Pertama, saat panen jagung semua anak-anak dari rumah itu harus bawa panen ke rumah adat walaupun dia bekerja di Dili atau Bacau. Lalu di situ ketua adat bersembahnyang sesuai nenek moyang kasih tahu. Kemudian tetua kasih sirih pinang untuk dibawa ke tempat semula. Kedua, pada saat ada anak yang dari luar ingin kenal menjadikan keluarga sirih pinang masuk lapor ke ketua adat di situ untuk lapor (minta ijin) dengan mengatakan rumah adat mana. Lapor ke bapak tetua adat untuk mendoakan. Ketiga, pada bulan Desember atau pergantian tahun, ketua adat mengundang semua anggota untuk mengadakan perundingan bagaimana cara memperhatikan rumah itu selanjutnya. [In a secret traditional house ("uma lisan"), the oldest who is the leader does not go anywhere but in that place for life. His goal as long as he waited for the house is to lead an adat event. Annually, there are 2-3 times custom events. First, during the corn harvest, all children from the house must bring the harvest to the traditional house even though they work in Dili or Bacau. Then, there the traditional leader prayed according to what the ancestors told him. Then the elders give betel nut to be brought to their original place. Second, when a child from outside wants to get acquainted, the betel nut family enter, report to the customary leader there to report (ask permission) by saying which traditional house. Report to the father of the elders to pray. Third, in December or the turn of the year, the customary leader invites all members to negotiate how to look after the house next] (FBP, 11/26/2018).

In addition to the three main events, the people of Timor Leste will also come to "uma lisan" to ask for security and luck. For people who want protection from their ancestors, they will ask for "betel nut" or "boa malus" from "lia nain". "Lia nain" will take the betel nuts and betel to be given spells (hamulak). One to be carried by "lia nain" and the other is addressed to the requestor. "Boa malus" brought by the requester will be a "talisman" that is believed to provide protection and good luck. Interviewees stated: "Saya sendiri ketika tahun 2008 ingin pergi ke Jogja, saya mendapatkan buah malus. Buah malus sebagai atas nama nenek moyang yang akan melindungi saya di luar sana. Juga untuk kesuksesan saya di luar sana" ["In 2008, I wanted to go to Jogja, I got malus fruit. Boa malus serves on behalf of the ancestors who will protect me out there. Also, for my success out there"] (PS / 26/11/2018). The ability of "uma 
lisan" in this case "Lia Nain" to provide security and protection was confirmed by $24 \%$ of the respondents who strongly agreed, and $43 \%$ agreed, $74 \%$ of the respondents strongly agree, and $23 \%$ agree that "uma lisan" still has sanctity, so they perform worship and other traditional rituals in order to ask for protection from various dangers.

"Lia nain" can also serve as mediator and judge during the conflict in the community. The conflict resolution authority was obtained from "lulik" who gave power to "lia nain" to give karmic punishment to anyone who opposed his decision. Therefore, when both parties involving in conflict are invited by "lia nain" they will surely come and comply with the decision. During the interview, Bacau, the spokesperson of "uma lisan" explained:

Korban melaporkan kepada petinggi adat. Dia (petinggi adat) akan memanggil para tetua adat. Dia akan memanggil pelaku, dan pelaku pasti datang karena adat paling tingi punya kekuatan. Jika pelaku tidak datang, maka adat akan membuat acara ritual untuk mendoakan yang negative kepada pelaku. Mungkin dia tidak merasakan saat ini, tapi turun termurun dia pasti akan merasakan. Orang tunduk karena takut karmanya [The victim reported to the customary leaders. He (traditional leader) will call the traditional elders. He will call the perpetrator, and the perpetrator will come because the highest custom has power. If the perpetrator does not come, then the adat will make a ritual to pray for negativity to occur to the perpetrator. Maybe he did not feel the result at this moment, but his descendant would definitely feel. People submit because of fear of karma.] (FAM, 11/22/2018)

"Lia nain" will resolve conflict by holding a "nahe biti boot" or "spread a large mat". The forum will be attended by the conflicting parties and/or other "uma lisan" elders when the conflict involved a different "uma lisan". The result of the "nahe biti boot" process will be reconciliation that bring peace to the conflicting parties. This reconciliation is marked by a slaughtering ceremony where the meat is then cooked and eaten together (FAM, 11/22/2018). Customary mechanisms can also be used to resolve murder cases. The case will usually end with reconciliation by the perpetrator giving compensation to the victim as a symbol of apology and the end of the conflict. The conflict that was successfully resolved was followed up with the creation of "tara bandu". "Tara bandu" is a joint agreement which is legalized by the higherups or elders in the area so that they must obey one legal custom. "Tara bandu" was made to ensure that similar conflicts did not recur (FAM, 11/21/2018).

Ketika ada pembunuhan maka dibayar kembali. Pelaku takut akan kehidupan selanjutnya maka datang ke korban dia minta supaya diselesaikan dengan membersihkan sebuah pendarahan. Dia membayar kembali korban dengan barang yang tidak bisa dimakan dan tidak boleh hilang untuk menggantikan seseorang dan dengan barang yang bisa dipakai. Artinya emas, kerbau, sapi, kuda. Emas dipakai oleh keluarganya sebagai lambang pengganti orang yang dibunuh. Dengan demikaian tidak ada lagi rasa dendam diantara kedua keluarga [When there is a murder, it is paid back. The perpetrator is afraid of the afterlife, so the perpetrator comes to the victim asking to be solved by cleaning up by bleeding. The perpetrator paid the victim back with items that could not be eaten and could not be lost to replace someone and with items that could be used. It means gold, buffalo, cow, horse. His family uses gold as a symbol of a substitute for the person killed. Thus, there is no longer any sense of revenge between the two families] (FAM, 11/22/2018).

The substantial role of "uma lisan" in resolving community conflicts is reflected in people's opinion, where about $77 \%$ respondents value this traditional institution's role in providing security and peace mechanism for local community. Specifically, the respondents also acknowledge that nahe biti boot becomes an effective mechanism for obtaining a resolution of the conflict they were experiencing. Majority of respondents (44\% stated strongly agree and $36 \%$ agree) believe that nahe biti boot has taken significant role in resolving the conflicts. 
Community compliance with the results of the mediation agreement conducted by "lia nain" was very high. It can be seen from the $29 \%$ of the respondents who stated strongly agree and $41 \%$ agreed to adhere to "tara bandu". Respondents will also comply with the agreement as a result of their compliance with "lia nain" as the guardian of "tara bandu", 51\% of the respondents stated strongly agree, and $40 \%$ agreed to comply with lia nain.

\section{The Role of the Church in Protecting Refugees and Resolving the Loromanu-Lorosa'e Conflict}

The church is a safe place for the people of Timor Leste to unite the people in opposing the Indonesian government. Interviewees, who were a church activist and experienced the tragedy of Santa Sruz stated that:

Mahasiswa mencari perlindungan dari Uskup Belo (di sini kan pastoran uskup belo) ...setelah penembakan santa Cruz, uskup Belo mendatangi Santa Cruz. Habis itu mahasiswa kembali berlindung di sini (Gereja Katedral Dili) [Students are seeking protection from Bishop Belo (here is the bishop of the Belo) ... after the shooting of Santa Cruz, Bishop Belo went to Santa Cruz. After that, students return to take refuge here (Church of Dili Cathedral] (PS, 22/11/2018).

This statement reinforces similar findings stating that people always sing their opposition to the occupation during Church services and pray for salvation. The priests will also let the protesters stay in their homes during the crisis, while the monastery will protect thousands of other refugees ${ }^{42}$. The church is the primary provider of protection for people who oppose the atrocities of the Indonesian Armed Forces ${ }^{43}$. In addition, the Church also delivered non-violent protests and criticized the brutality of the Indonesian military.

The church remains a safe haven for people who were severely affected by the postreferendum riots and political conflicts in 2006-2008. In his statement a Church congregation stated:

99 (tahun 1999 pasca referendum) juga ini (Gereja Katedral Dili) sebagai tempat pengungsiaan. Apalagi Tahun 2006 itu penuh pengungsi. Semua yang bukan merasakan sebagai seorang musuh atau korban itu ke sini...mereka campur [99 (in 1999 after the referendum) also this (Dili Cathedral Church) is as a place of refuge. Moreover, 2006 was full of refugees. All those who do not feel as an enemy or victim are here ... they are mixed] (PS, 22/11/2018).

Two informants who were the victims uring the 2006-2008 riots confirmed that the church was their sanctuary. They stated that they felt safer to evacuate in the church than at home. They believed that the church as a holy place would not be attacked by rioters. In addition, they are also increasingly easy to get humanitarian assistance that comes from the Catholic Relief Service and other aid agencies.

Ketika 2006, Saya umur 7 tahun...Kami tinggal berbatasan dengan susteran Salesiana. Terus untuk menyelamatkan diri kami lari dengan membawa barang-barang kami dibantu oleh kakak kakak yang besar. Situasi kala itu tidak aman kala tinggal di rumah saja karena di tempat lain sudah bakar-bakar rumah. Kami tinggal di susteran untuk beberapa bulan. Terus pindah dari Selesiana ke Susteran Kanosiana. Tahun 2007 kami pindah dari Kanosiana ke rumah

\footnotetext{
${ }^{42}$ McGregor, Andrew., Skeaff, Laura., \& Bevan, Marianne: "Overcoming Secularism Catholic Development Geographies in Timor-Leste, Third World Quarterly, Vol. 33, n ${ }^{\circ}$ 6, pp. 1129-1146, at https://doi.org/10.1080/01436597.2012.681497

${ }^{43}$ Leach, Michael: "The Politics of History in Timor Leste", in Ingram, Sue., Kent, Lia., McWilliam, Andrew (eds.) (2015): A New Era ?: Timor-Leste after the UN, Canberra, ANU Press, pp. 41-58.
} 
dibantu oleh Catholic Relief Service. [In 2006, I was 7 years old ... We lived adjacent to the Salesiana sister. Continuing to save ourselves we ran away with our belongings assisted by big brothers. The situation at that time was not safe when we stayed at home because in other places there were already burning houses. We stayed with the sisters for several months. Then we move from Selesiana to Kanosiana. In 2007 we moved from Kanosiana to a house assisted by Catholic Relief Service] (ZGL, 11/29/2018).

Kami mengungsi lagi pas tembakan itu, tanggal 24 Mei 2006 tembak-tembakan. Kami mengungsi di sekolah-sekolah yang dekat Gereja Santo Josep. Orang-orang pergi ke Gereja, Sekolah, Seminari karena orang tidak akan masuk ke sana. Kita tinggal di tenda, kami tidak boleh ke rumah kami karena rumah kami sudah dibakar lagi sama orang-orang daerah sebelah saya (Kaikoli) yang ditinggali oleh kebanyakan orang loro manu. Kami mengungsi lagi 2006, 2007 terus 2008 kembali lagi." [We retook refuge when the shots were fired, on May 24, 2006, shooting happened. We sought refuge in schools near the Church of Saint Josep. People go to Church, School, and Seminary because people will not go there. We live in tents; we cannot go to our homes because our houses have been burned down again by the people in the area next to me (Kaikoli) who are mostly inhabited by people of Loromanu. Again, we evacuated in 2006, 2007, and then again in 2008]. (CIAS, 11/29/2018)

The role of church as a refuge during the time of conflicts was confirmed by majority of respondents ( $73 \%$ respondents agreed). While $22 \%$ respondents stated neutral, and only $5 \%$ disagreed. It shows that the community believes in the church's ability to provide security for them. Not only during the 1999 and 2006 conflicts but until 2018 the community still believes that the church can be a safe place for them. The church is able to provide protection to refugees and the community in general because facilities support it. The church is an integrated environment consisting of a parish church, a monastery for priests, brothers and sisters, a residence for children and usually a plot of land to grow food for the school kitchen. From here, they can provide food, clothing, and primary medical care, and support for widows, victims of physical and sexual violence, and orphans. This safe space is very important for women seeking protection from sexual violence, which is often used as a weapon of war by the Indonesian military. Many religious groups, such as the Canossians and Carmelites, set up special shelters for young girls to help them escape the threat of rape or recover. The holistic care they offer is spiritual and physiological, which increasingly attracts people's faith to overcome suffering ${ }^{44}$.

Furthermore, the church also has important role in peace process when conflicts within or between the communities occur. Conflict in 2006, for instance, which experienced an escalation to involve the people of kaladi/loromanu and firaku/Lorosa'e, was able to be reconciled by the church. During 2006-2008, the priests oftentimes delivered peaceful messages to end the communal conflict. "Uskup, mereka menghimbau tidak ada orang Lorosa'e Loromanu. Kita sama dihadapan Tuhan" ["Bishop, they call for no Lorosae Loromanu. We are the same before God (CIAS, 11/29/2018)". Another informant stated that:

Krisis-krisis di Timor semenjak tahun 1999-2006, peran gereja itu salah satunya di perayaan ekaristi (misa kudus) di hari minggu. Pastor dalam humili-nya terlebih dahulu membacakan Evangelho (inti bacaan yang diambil dari Alkitab). Nah pastor-pastor dalam humili-nya disesuaikan dengan kondisi (konflik) yang ada”. Setalah humili selesai, pastor akan meminta kepada jemaat untuk saling damai. Ketika jemaat mau menerima persembahan ini, maka artinya mereka berdamai dengan Tuhan dan juga kepada manusia sesama. [The crises in Timor since 1999-2006, one of the roles of the church is in the celebration of the Eucharist (Holy Mass) on Sundays. The priest in his homily first reads Evangelho (the main reading taken from the Bible). Now the priests in their homily adapted to the existing (conflict) conditions.

${ }^{44}$ Mc Gregor and Bevan, op.cit. 
After the homily is over, the priest will ask the congregation to be mutually peaceful. When the congregation is willing to accept this offering, it means they are at peace with God and also with fellow humans] (PS, 11/22/2018).

The church successfully reconciled Lorosa'e and Loromanu people who involved in the ethnic conflict in 2006-2008. One of the church members admitted by stating that: "setelah misa Natal, masyarakat Lorosa'e dan Loromanu yang berada di Gereja saling bersalaman dan berpelukan. Kami saling memaafkan dan tidak ada masalah lagi antara kami" ["After Christmas Mass, the Lorosae and Loromanu people who were in the Church shook hands and embraced each other. We forgive each other, and there are no more problems between us"] (Anonymous/5/11/2018). Another experience was reported by other informant, where he experienced reconciliation in his home environment after the Christmas Eve celebration in his village in the Comoros. "Kami menyalakan lilin bersama dan kemudian saling berjabat tangan untuk maaf memaafkan" ["We lit candles together and then shook hands with each other to apologize for forgiveness"] (PS/22/11/2018).

The success of the church in reconciling communal conflicts has been supported by several factors. First, the high public confidence in church leaders. This is confirmed by the majority of respondents, $75 \%$ of them believed on the important role of church leaders in reconciling the parties to the conflict in 2006-2008. Second, the high confidence of the East Timorese people about the role of religious norms in reconciling conflict. About $93 \%$ of respondents agreed that the religious norms became a reference for peaceful living in society. And third, the high level of community obedience in performing their religious beliefs which reflected in $97 \%$ respondents stating their obedience in practicing their religion.

\section{Subtitution Relations "Uma Lisan" and the Church in Covering the Weaknesses of the PNTL and the Court in Providing Security for the East Timorese Community}

This research found that "uma lisan" and the church has played notable role in providing security and peace for the people of Timor Leste. "Uma lisan" played this role through the protection provided by "lulik". In the spiritual land scape of the East Timorese people, "lulik" is believed by the people of Timor Leste to provide destruction while at the same time providing protection from all dangers ${ }^{45}$. The people of Timor Leste will ask for protection and the goodness of life through several rituals such as during harvest, marriage, and also through sirih pinang or boa malus media. This belief in the power and power of "lulik" has an impact on the perception that security is rooted in harmonious relations between humans and ancestors, nature, and with other humans. Therefore, the people of Timor Leste will try to maintain harmony in order to avoid damage that comes from the power of "lulik". "Lulik" not only symbolizes the power of "God" but also a source of values and norms that can regulate human life. "Uma lisan" translates these values and norms in the form of a peaceful conflict resolution mechanism. "Lia Nain" who has the power comes from "lulik" will invite the parties involved in the conflict in mediation on a large mat (nahe biti boot). Nahe biti boot provides an opportunity for both parties to the conflict to raise the issue and then seek a mutual agreement to end the conflict ${ }^{46}$. The agreement reached will be ratified as tarabandu which then binds to the relevant parties. This adat mechanism is felt to be more effective in resolving community

\footnotetext{
${ }^{45}$ See McWilliam, Andrew., Palmer, Lisa., \& Shepherd, Christopher: "Lulik Encounters and Cultural Frictions in East Timor: Past and Present". Australian Journal of Anthropology, Vol. 25, $\mathrm{n}^{\circ}$ 3, (2014), pp. 304-320, at https://doi.org/10.1111/taja.12101; also see Winch, Bronwyn: " 'La iha fiar, la iha seguransa ': the Spiritual Landscape and Feeling Secure in Timor-Leste", Third World Thematics: A TWQ Journal, Vol 2, n 2-3 (2017), pp. 197-210, at https://doi.org/10.1080/23802014.2017.1320200.

${ }^{46}$ Babo-Soares, Dionísio: "Nahe Biti: The Philosophy and Process of Grassroots Reconciliation (and Justice) in East Timor, Asia Pacific Journal of Anthropology, Vol 5, n 1 (2004), pp. 15-33, at https://doi.org/10.1080/1444221042000201715
} 
problems because the process is fast, uncomplicated, and the results will be followed by the parties concerned as a result of their fear of punishment from a greater ancestor if they deny the decision.

In providing security, the church serves as a source of strength for liberation as well as place for protection for East Timorese youth during the struggle against Indonesian army ${ }^{47}$. Although the church was not proportionally involved by the United Nations in the formation of the state of Timor Leste and was also kept away from the function of the state, the church chose to carry out its functions along with the functions of the state ${ }^{48}$. The security role of the Church can be seen from its ability to influence people's perception of security. In contrast to "uma lisan", the Church has a source of security reference that comes from the Lord Jesus. God is the one who has the power to make disaster or peace in human life. Through a set of values and norms governed in the Catholic religion, the people are asked to be obedient in order to obtain security and peace. With a high level of religious observance in the community of Timor Leste, the community has also based its peaceful behavior on Catholic teachings.

The church has always played an important role in the development of East Timorese society ${ }^{49}$. The role of security felt by the community is the protection from violence. During the struggle against Indonesia, the church became a clandestine shelter and youths who resisted. This role was repeated during the conflict in 1999 and in 2006-2008, where the church was a refuge for refugees. The church provided shelter as well as logistics supported by a network of international cooperation and the trust of the East Timorese people who consider the church a holy place that must be free from violence. The church also played valuable role of conflict resolution utilizing mediation and reconciliation during the 2006-2008 conflict at the community level. Pastors frequently convey messages of peace and actually act as reconciler between the Loromanu and Lorosa'e people. The church has used the momentum of worship and Christmas to reconcile the Lorosae and Loromanu people.

Looking at the roles of "uma lisan" and the church that are in line with the goals of the PNTL institution and the state court, both institutions have a complementary or substitutive pattern of relations. "Uma lisan" was able to cover up the weaknesses of PNTL in protecting community security during the 2006-2008 conflict and was able to cover the weaknesses of the judiciary in resolving conflicts in the community. Meanwhile, the church was able to replace the function of protecting refugees when the PNTL failed to carry out its functions during the 2006-2008 conflict. The church also has been successfully become negotiator in helping with the reconciliation process to end the communal conflict in 2006-2008. The success of the "uma lisan" and the church in performing the complementary functions of security is what makes the people of Timor Leste still get their security when state-led security institutions fail to carry out their functions.

\footnotetext{
${ }^{47}$ Hodge, Joel: (2013). "The Catholic Church in Timor-Leste and the Indonesian Occupation, South East Asia Research, Vol. 21, $\mathrm{n}^{\mathrm{o}} 1$ (2013), pp 151-170, at https://doi.org/10.5367/sear.2013.0134

${ }^{48}$ Carey, Peter.: "The Catholic Church, religious Revival, and the Nationalist Movement in East Timor, 1975-98, Indonesia and the Malay World, Vol. 27, $\mathrm{n}^{\circ} 78$ (2007), pp. 77-95, at https://doi.org/10.1080/13639819908729935 ${ }^{49}$ See McGregor and Bevan, op.cit.
} 
Table 2. The Role of Informal Institutions and their Relation to Formal Security Institutions

\begin{tabular}{|c|c|c|c|}
\hline Institution & Safety Reference & Security Role & $\begin{array}{l}\text { Relations with State security } \\
\text { institutions }\end{array}$ \\
\hline \multirow[t]{3}{*}{ "uma lisan" } & "lulik" & $\begin{array}{l}\text { 1. Instilling security values and } \\
\text { norms for the community based } \\
\text { on traditional mechanism. }\end{array}$ & Substitution \\
\hline & & $\begin{array}{l}\text { 2. Providing protection to the } \\
\text { community from danger. }\end{array}$ & \\
\hline & & $\begin{array}{l}\text { 3. Providing Alternative dispute } \\
\text { resolution by nahe biti boot and } \\
\text { tarabandu }\end{array}$ & \\
\hline \multirow[t]{3}{*}{ Church } & God & $\begin{array}{l}\text { 1. Instilling security values and } \\
\text { norms for the community based } \\
\text { on catholic faith. }\end{array}$ & Substitution \\
\hline & & $\begin{array}{l}\text { 2. Providing protection for } \\
\text { refugee and other victims of } \\
\text { conflict. }\end{array}$ & \\
\hline & & $\begin{array}{l}\text { 3. Providing Alternative dispute } \\
\text { resolution by reconciliation and } \\
\text { mediation. }\end{array}$ & \\
\hline
\end{tabular}

The substitution role of the church and "uma lisan" was confirmed by both Lorosa'e and Loromanu people who were involved in the ethnic conflict of 2006-2008. Based on independent sample t-test, it is known that the value of sig. (2-tailed) is 0.970 , so it is higher than 0.05 . The results of the independent test that have been done show that there is no difference in perceptions between the people of Lorosa'e and Loromanu when view the role of church institutions and "uma lisan" in providing security and conflict resolution mechanisms.

Table 3. Independent Sample T-Test

\begin{tabular}{|c|c|c|c|c|c|c|c|c|c|c|}
\hline & & \multicolumn{2}{|c|}{ Equality of Variances } & \multicolumn{7}{|c|}{ t-test for Equality of Means } \\
\hline & & \multirow[b]{2}{*}{$\mathrm{F}$} & \multirow[b]{2}{*}{ Sig. } & \multirow[b]{2}{*}{$t$} & \multirow[b]{2}{*}{ df } & \multirow{2}{*}{$\begin{array}{l}\text { Sig. (2- } \\
\text { tailed) }\end{array}$} & \multirow{2}{*}{$\begin{array}{c}\text { Mean } \\
\text { Difference }\end{array}$} & \multirow{2}{*}{$\begin{array}{l}\text { Std. Error } \\
\text { Difference }\end{array}$} & \multicolumn{2}{|c|}{ Interval of the } \\
\hline & & & & & & & & & Lower & Upper \\
\hline \multirow[t]{2}{*}{ Nilai } & $\begin{array}{l}\text { Equal variances } \\
\text { assumed }\end{array}$ & .000 & .997 & .038 & 98 & 970 & .078 & 2.043 & -3.977 & 4.133 \\
\hline & $\begin{array}{l}\text { Equal variances } \\
\text { not assumed }\end{array}$ & & & .038 & 26.792 & 970 & .078 & 2.064 & -4.159 & 4.315 \\
\hline
\end{tabular}

\section{Conclusion}

This research examined that the relationship between informal institutions and formal institutions in the security sector has an important effect on the success or failure of building security in post-conflict societies. The substitution relations overcome the weaknesses or failure of state-led institutions in performing their security functions. The failure or weakness of the PNTL security institutions and the courts in providing security for the people of Timor Leste, particularly during the period 2002-2012, has been covered by the substantial role of the "uma lisan" and the church in providing security and peaceful conflict resolution mechanisms. "Uma lisan" is still a source of reference for the people of Timor Leste in perceiving security and seeking protection from "lulik". In addition, "uma lisan" is also able to provide conflict resolution mechanism outside the state court mechanism for almost all criminal and civil matters. The role of the church can substitute the role of the police by forming perceptions of security based on Catholic values and also providing protection for victims of conflict. The church also has carried out a mediation role to resolve conflicts that occur in the community. 
Although the "uma lisan" and the church were not directly involved with the UN in building the security sector in Timor Leste, both informal institutions performed substitution functions. In this research, the writer cannot explain yet the motives behind the complementary choices of the two institutions. Therefore, the problem of the substitution of the "uma lisan" and the church is the topic of the next research agenda. This research recommends the UN to perform its peace mission not only focusing on building formal institutions, but also involving and strengthening informal institutions as an essential pillar for state building in post-conflict areas. The recommendation for the government of Timor Leste is clear: They need to strengthen the cooperation of formal institutions with informal/traditional institutions for managing security in Timor Leste.

\section{Bibliography}

Armstrong, Nicholas. J., Chura-Beaver, Jacqueline., \& Kfir, Isaac.(2012): Security Sector Reform in Timor-Leste: Missed Opportunities and Hard Lessons in Empowering the HostNation, Pennsylvania: Peacekeeping and Stability Operations Institute (PKSOI)

Azari, Julia. R., \& Smith, Jennifer. K: "Unwritten rules: Informal Institutions in Established Democracies", Perspectives on Politics, Vol. 10, nº 1 (2012), pp.37-55 at https://doi.org/10.1017/S1537592711004890

Babo-Soares, Dionísio.: "Nahe Biti: The Philosophy and Process of Grassroots Reconciliation (and Justice) in East Timor, Asia Pacific Journal of Anthropology, Vol 5, no 1, (2004), pp. 1533, at https://doi.org/10.1080/1444221042000201715

Baldwin, David A.: "The Concept of Security", Review of International Studies, Vol. 23, n 5 (1997), pp. 5-26.

Besenyő, János: "Barry Buzan's Securitization Theory and the Case of Iraqi Kurdish Military Action Against ISIS in 2014", Journal of Security and Sustainability Issues Vol. 8, nº 3 (2019), pp. 295-306 at http://doi.org/10.9770/jssi.2019.8.3(1)

Blanco, Ramon: "The UN Peacebuilding Process: an Analysis of Its shortcomings in TimorLeste", Revista Brasileira de Política Internacional, Vol. 58, $\mathrm{n}^{\mathrm{0}}$ 1, pp. 42-62, at https://doi.org/10.1590/0034-7329201500103

Butler, Michael J.: "Ten Years After: (Re) Assessing Neo-Trusteeship and UN State-building in Timor-Leste", Journal of International Studies Perspectives, Vol.13, nº 1 (February 2012), pp. 85-104.

Carey, Peter: "The Catholic Church, religious Revival, and the Nationalist Movement in East Timor, 1975-98, Indonesia and the Malay World, Vol. 27, $\mathrm{n}^{\circ} 78$ (2007), pp. 77-95, at https://doi.org/10.1080/13639819908729935

Chinn, Liam and Everett, Silas (2008): A Survey of Community-Police Perceptions Timor-Leste in 2008, San Francisco, The Asia Foundation

Chopra, Jarat: "Building State Failure in East Timor", Development and Change Vol.33, n'5(2002), pp. 979-1000, Oxford, Blackwell Publishers.

Creswell, John.W. (2014): Research Design: Qualitative, Quantitative, and Mixed Methods Approaches, Thousand Oaks, Sage Publication.

Gjørv, Gunhild Hoogensen.: "Security By Any Other Name: Negative Security, Positive Security, And a Multi-Actor Security Approach", Review of International Studies, Vol.38, $\mathrm{n}^{\mathrm{O}} 4$ 
(2012), pp. 835-859, at https://doi.org/10.1017/S0260210511000751

Gordon, Eleanor: "Security Sector Reform, Local Ownership and Community Engagement. Stability", International Journal of Security \& Development, Vol. 3, nº 1, (2014), pp. 1-18, at http://dx.doi.org/10.5334/sta.dx.

Grenfell, Damian., \& Winch, Bronwyn.(2014): Local Security And Resilience, Centre For Global Research and the Asia Foundation.

Helmke, Gretchen. and Levitsky, Steven: "Informal Institutions and Comparative Politics: a Research Agenda", Perspective on Politics, Vol 1, no 4 (December 2004), pp. 725-740.

Hodge, Joel.: "The Catholic Church in Timor-Leste and the Indonesian Occupation, South East Asia Research, Vol. 21, no 1 (2013), pp 151-170, at https://doi.org/10.5367/sear.2013.0134

Hood, Ludovic.: "Security sector reform in East Timor, 1999-2004", International Peacekeeping, Vol.13, $\mathrm{n}^{\circ} 1$ (2006) pp. 60-77, at https://doi.org/10.1080/13533310500424819

Jackson, Paul.: " Security Sector Reform and State Building", Third World Quarterly, Vol. 32, $\mathrm{n}^{\mathrm{o}} 10$ (2011), p.1804.

Kohl, Christoph (ed.): "The Reform of Guinea-Bissau's Security Sector: Between Demand and Practice", PRIF Reports No. 126, (2014), at http://nbn-resolving.de/urn:nbn:de:0168-ssoar435339.

Leach, Michael: "The Politics of History in Timor Leste", in Ingram, Sue., Kent, Lia., McWilliam, Andrew. (eds.) (2015): A New Era? Timor-Leste after the UN, Canberra, ANU Press, pp. 41-58.

Marx, Susan. (2103): Timor Leste Law and Justice Survey, San Francisco, the Asia Foundation.

McGregor, Andrew., Skeaff, Laura., \& Bevan, Marianne.: "Overcoming Secularism Catholic Development Geographies in Timor-Leste, Third World Quarterly, Vol. 33, nº 6 (2012), pp. 1129-1146 at https://doi.org/10.1080/01436597.2012.681497

McWilliam, Andrew., Palmer, Lisa., \& Shepherd, Christopher.: "Lulik Encounters and Cultural Frictions in East Timor: Past and Present". Australian Journal of Anthropology, Vol. 25, $\mathrm{n}^{\circ} 3$, (2014), pp. 304-320, at https://doi.org/10.1111/taja.12101

Menocal, Alina Rocha.: "State Building for Peace: A New Paradigm for International Engagement in Post-Conflict Fragile States?", Third World Quarterly, Vol. 32, no 10 (2011), pp. 1715-1736.

Miall, Hugh. (2004): Conflict Transformation: A Multi-Dimensional Task, Berlin, Berghof Research Center for Constructive Conflict Management.

OECD DAC. (2007): OECD DAC Handbook on Security System Reform. Paris, OECD, in United Nations: "Securing Peace and Development: The Role of the United Nations in Supporting SSR.” Report of the Secretary-General. A/62/659-S/2008/39. (January 23, 2008).

Onoma, Ato Kwamena: "Transition Regimes and Security Sector Reforms in Sierra Leone and Liberia", WIDER Working Paper, no 012 (January 2014), at http://hdl.handle.net/10419/96283.

Radin, Andrew (2012): “A Laboratory for State Building: Police and Military Reform in East Timor", Working Paper, No. 2012-11, Massachusetts, Massachusetts Institute of Technology Political Science Department.

Ramos, Arquimino Bianco Leuidi (2014): Reformasi Sektor Keamanan, Kupang, Gita Kasih. 
Schroeder, Ursula C., Chappuis, Fairlie., \& Kocak, Deniz: "Security Sector Reform and the Emergence of Hybrid Security Governance", International Peacekeeping, Vol. 21, nº.2 (2014), pp. 214-230, at https://doi.org/10.1080/13533312.2014.910405

Sedra, Mark.: "The Evolution of the Security Sector Reform Agenda", in Sendra, Mark (ed.) (2010): The Future of Security Sector Reform, Waterloo, Canada, The Centre for International Governance Innovation.

Simangan, Dahlia: "A Detour in the Local Turn: Roadblocks in Timor-Leste's Post-Conflict Peacebuilding", Asian Journal of Peacebuilding, Vol 5, n.2 ( January 2017), pp. 195-221.

Uesugi, Yuji.: "Security Sektor Reform (SSR) in Timor-Leste: The Challenges of Respecting Local Ownership", Asia Peacebuilding Inisiatives, (2014).

UN Security Council. (2002): Report of the Secretary-General on the United Nations Transitional Administration in East Timor, Number S/2002/432, New York, UN Security Council

UN Security Council. (2012): Report of the Secretary-General on the United Nations Integrated Mission in Timor-Leste (for the period from 7 January through 20 September 2012), Number: S/2012/765, New York, UN Security Council.

Valters Craig, Dewhurst Sarah and de Catheu Juana: "After the Buffaloes Clash Moving from Political Violence to Personal Security in Timor Leste", January 2015. Overseas Development Institute at

https://www.odi.org/publications/9190-after-buffaloes-clash-moving-political-violencepersonal-security-timor-leste

Wassel, Todd and Rajalingam, Gobie (2013): A Survey of Community-Police Perceptions in Timor-Leste 2013 Survey, San Francisco, the Asia Foundation.

Wassel, Todd. (2014): Timor-Leste : Links Between Peacebuilding, Conflict Prevention and Durable Solutions to Displacement, Washington, D.C.: Brookings Institution.

William, Paul D. (2008): Security Studies: An Introduction, London, Routledge, pp. 5-10.

Wilson, BuV. E.: To 2012 and Beyond: International Assistance to Police and Security Sector Development in Timor-Leste. Asian Politics and Policy, Vol 4, $\mathrm{n}^{\circ}$ 1, (2012), pp. 73-88 at https://doi.org/10.1111/j.1943-0787.2011.01320.x

Winch, Bronwyn: "'La iha fiar, la iha seguransa': the Spiritual Landscape and Feeling Secure in Timor-Leste", Third World Thematics: A TWQ Journal, Vol 2, n 2-3 (2017), pp. 197-210, at https://doi.org/10.1080/23802014.2017.1320200. 